\title{
Archbishop Desmond Tutu as moral sage and servant leader: A compassionate zealot
}

\author{
R Rensburg \\ (University of Pretoria)
}

\begin{abstract}
Archbishop Desmond Tutu as moral sage and servant leader: A
compassionate zealot
\end{abstract}

Desmond Mpilo Tutu, Archbishop emeritus, has been a prominent character in the global sphere for many years and more recently he has established himself as one of the great leaders in the world. This article investigates transformational and charismatic leadership, as well as the concept of zealotry and comes to the conclusion that the leadership of Desmond Tutu is a synthesis of elements of pragmatic, transformational and charismatic leadership. The article further describes the Archbishop as a servant leader with elements of self-sacrifice, and a zealot with deep compassion for people and causes. Desmond Tutu remains a leading moral and reconciliatory voice across the globe.

\section{INTRODUCTION}

Houghton (Hambrick et al 1998:28) maintains that leadership is a willingness to change everything except basic values and goals, a continual dissatisfaction with "things as they are", as well as a drive to change things for the better. One key social skill that appears to underlie leader performance is social perceptiveness. Indeed, a strong case is made that leadership reflects a function that needs to be carried out regardless of time or place. It also has institutional roots throughout the globe. So leadership, in some form, appears to be universal throughout the developed and less developed countries.

Archbishop Desmond Tutu is a leader in the truest sense of the word. Firm and steadfast in his views and way of life, his ideas now are as unchangeable as his ideas during the apartheid regime. He remains one of a few world leaders who retained their views regardless of the changing surrounding circumstances. He was a maverick spirit who became the voice of black South Africa under apartheid, a man of immense moral authority. Under his vigorous leadership, the church in South Africa became immersed in the political struggle. He constantly told the government of the time that its racist approach defied the will of God and for that reason could not succeed. But Archbishop Tutu has also 
not been uncritical of the ANC government. A couple of years ago he complained that some politicians were jumping on the "gravy train". In a recent interview he remarked (Shapiro 2002):

"We have to keep reminding people why we have struggled against apartheid. Now we've got to give credit for the fact that we have a remarkable stability in South Africa, but we need to get rid of the crime, the unemployment, and ensure that people will say, 'Yes, there is a qualitative difference between repression and democracy. Let's make sure we become a democracy where debate and dissidence are things that we welcome'...."

Before 1990, Archbishop Tutu's vigorous social perceptiveness and advocacy of social justice made him a figure of controversy. Today he is seen more as an elder statesman with a major role to play in reconciliation, and as a leading moral voice across the globe. If one scans the literature on leadership, it becomes clear that the Archbishop displays a synthesis of transformational, charismatic and pragmatic leadership, as well as a touch of zealotry. This remark warrants a closer look into these types of leadership.

\section{TRANSFORMATIONAL AND CHARISMATIC LEADER- SHIP}

Scholars have long debated exactly what makes exceptional, outstanding leadership possible. What allowed Julius Caesar, George Washington, and Joan of Arc to exercise such profound influence on their contemporaries? (Mumford and Van Doom 2001:9).

In recent years, the quest to understand outstanding leadership has focused on the characteristics of charismatic and transformational leaders. An explanation for this might be the fact that charismatic and transformational leaders provide the world with a motivating sense of identity by presenting and articulating a vision (Shamir \& Ben-Arie 1999). Beginning with Weber's (1947) examination of notable historic leaders, scholars of leadership have examined the merits of using the concept of charisma, and the closely related broader concept of transformational leadership, and concluded that charismatic and transformational leadership can account for many incidents of exceptional leadership. Leaders provide followers with meaning by constructing and communicating a vision, or image, that articulates followers' values while allowing them to express their identity through a shared collective vision. This appeal to values and identity, not only motivates people to work towards an envisioned future, but also serves to build feelings of 
competence and self-worth (House \& Shamir 1993; Mumford et al 2000).

\subsection{Describing transformational and charismatic leadership}

Although virtually all models of outstanding leadership stress the importance of vision, different scholars make different assumptions about other kinds of actions likely to play a part in exceptional leadership (Hunt 1991; Yukl 1994). In his description of charismatic leaders, House (1977) emphasises the importance of passion and self-sacrifice, displaying confidence in followers, and role modelling, among other dimensions. Conger and Kanungo (1998) hold that charismatic leaders assess the external environment to find weaknesses in the status quo, attracting followers by presenting an appealing vision that seems radically different from the current status quo.

Although there are similarities between charismatic and transformational leadership, the integrative style of transformational leaders stands in contrast to the distinctive vision characteristic of charismatic leaders. Another distinction between transformational and charismatic leadership is found in leader-subordinate relationships and their effects on motivation. Transformational leaders motivate followers through personal development and intellectual stimulation (Bass 1985). Motivation for followers of a charismatic leader is derived from a strong affective relationship with the leader - spiritual or hero-worship, and a leader's ability to instil self-efficacy (Shamir et al 1993).

\subsection{The components of transformational and charismatic leader- ship}

According to Bass (1985) transformational leadership is a multidimensional phenomenon and it involves more than just vision. Transformational leadership entails idealised influence (charisma), inspirational motivation, intellectual stimulation, and individualised consideration. The transformational and charismatic leader, like the Archbishop Tutu, is one who persuades through negotiation, participation and empowerment (Bass 1985). The transformational leader is concerned with aligning the personal values of followers to the objectives of an organisation, cause or society at large.

\section{Idealised influence}

If the leadership is transformational, its charisma or idealised influence is envisioning, confident, and sets high standards for emulation. Recent literature underscores the spiritual dimensions of such influence (Kanungo \& Mendonca 1996: 87ff; Fairholm 1998: Part V) as well as 
the moral dimensions of the influence process itself (Kanungo \& Mendonca 1996: 52-56). In addition to what has already been said, Howell and Avolio (1992) point out the need of authentic (as opposed to pseudo-) transformational leaders to promote ethical policies, procedures and processes. They need to be committed to a clearly stated, continually enforced code of ethical conduct which helps establish acceptable standards.

\section{Inspirational motivation}

The inspirational motivation of transformational leadership provides followers with challenges and meaning for engaging in shared goals and undertakings. The inspirational appeals of the authentic transformational leader tend to focus on the best in people - on harmony, charity and good works, while the inspirational appeals of the pseudo-transformational leader tend to focus on the worst in people - on demonic plots, conspiracies, unreal dangers, excuses, and insecurities. Kanungo and Mendonca (1996:61ff) have linked this to an empowerment process. For them, empowerment is more than broadening the scope of participation by followers. It is motivational and enabling, highlighting a new realisation and transformation of the person. Authentic transformational leaders are inwardly and outwardly concerned about the good that can be achieved for the group, organisation, or society for which they feel responsible. The pseudo-transformational leaders may publicly give the same impression and be idealised by their followers for it, but privately be concerned about the good they can achieve for themselves.

\section{Intellectual stimulation}

The intellectual stimulation of transformational leadership incorporates an open architectured dynamic into processes of situation evaluation, vision formulation and patterns of implementation. Such openness has a transcendent and spiritual dimension and helps followers to question assumptions and to generate more creative solutions to problems. It is especially suited to the normative side of ethics, where human probing of the ground of being is both fathomless and endless. To the point, this dynamic breaks the bonds of leadership cultures that ignore fundamental questions such as altruism (Kanungo \& Mendonca 1996: 79ff).

\section{Individualised consideration}

The individualised component of consideration of transformational leadership underscores the necessity of altruism if leadership is to be anything more than authoritarian control (Kanungo \& Mendonca 1996:85ff). The transformational leader treats each follower as an 
individual and provides coaching, mentoring and growth opportunities (Bass 1985). While authentic transformational leaders are concerned about developing their followers into leaders, pseudo-transformational leaders are more concerned about maintaining the dependence of their followers. They exploit the feelings of their followers to maintain deference from them (Sankowsky 1995). Pseudo-transformational leaders will welcome and expect blind obedience. They will attempt to enhance their personal status by maintaining the personal distance between themselves and their followers. They encourage fantasy and magic in their vision of the attractive future while true transformational leaders promote attainable shared objectives.

\subsection{The ethics of transformational and charismatic leadership}

The ethics of leadership rests upon three pillars: (1) the moral character of the leader; (2) the ethical legitimacy of the values embedded in the leader's vision, articulation, and a message that followers either embrace or reject; and (3) the morality of the processes of social ethical choice and action that leaders and followers engage in and collectively pursue. Such ethical characteristics of leadership have been widely acknowledged (Greenleaf 1977; Kanungo 1998; Wren 1998). Transformational leaders set examples to be emulated by their followers.

For many moral analysts, leadership is a many-headed hydra that alternately shows the faces of Saddam Hussein, Adolf Hitler, Osama Bin Laden and Pol Pot as well as those of Nelson Mandela, Archbishop Tutu and Mother Theresa. The stories that recount the accomplishments of such leaders raise moral questions concerning both the character of the leaders as well as the legitimacy of their programmes.

Following the ideas of Rogers and Farson (1955), Conger and Kanungo (1988) maintained that charismatic leadership (which they defined similarly to transformational leadership) of self-serving leaders could result in deception and exploitation of followers, but argued that most leaders pursued both personal and societal interests. Subsequently, Conger and Kanungo (1998:Chapter 7) reviewed the dark side of charismatic leaders: narcissisms, authoritarianism, Machiavellianism, flawed vision, a need for power, and a lack of internalisation of values and beliefs.

Authentic transformational leadership provides a reasonable and realistic concept of self - a self that is connected to friends, family, and community, whose welfare may be more important to them than their own. Their moral obligations are grounded in a broader conception of individuals within community and related social norms and cultural beliefs. Transformational leadership is consistent with Judaic-Christian 
philosophical traditions and discourses on the leadership of the moral sage that presuppose a trusting community as the central life context.

In leadership, character matters. This is not to deny that evil people can bring about good things or that good people can lead the way to moral ruin. Rather, leadership provides a moral compass and, over the long term, both personal development and the common good are best served by a moral compass that reads true. Here some lessons can be drawn from the traditions of the moral sage and social prophet that have enjoyed prominence in a wide variety of cultures. Whether visionary or ascetic, the moral sage and social prophet have also widely been perceived as agents of change, as well as people to be emulated and as leaders of others, not followers.

Both Socrates and Confucius have come to epitomise leaders with authentic idealised influence. There is no doubt that over the centuries they have taken on heroic dimensions. Their framing narratives underscore a fundamental dynamic of leadership. Each proposed to his followers the highest ethical standards that they themselves implemented in their own lives. More importantly, in terms of authenticity, each was recognised as a moral sage and leader by others, not by selfproclamation.

Historically, the central focus of ethical concern in Chinese traditions manifests a right ordering of personal relationships. Epitomised in Confucius" "five relations", (Tu 1985:chapter 3; Taylor \& Arbuckle 1995), Chinese ethics emphasises personal virtue and specify proper conduct in family, kinship, and friendship relations, as well as among social equals and between superiors and subordinates in sociopolitical organisations and institutions. The social and political order has always been seen as a moral issue and it plays a critical role in realising humanity's ethical destiny (Schwarz 1985:52; De Bary 1991). The virtue of ren (human-heartedness, benevolence) and the virtue of yi (righteousness) are the grounding virtues of the moral life. They express the way (dao) that one existentially embraces.

The moral person in each tradition would sacrifice anything for the sake of virtue. For example, the Confucian moral tradition is strikingly clear about the relation of profits to moral virtue. From the Analects (4.5) one reads:

"Confucius said, 'Wealth and honor are what every person desires. But if they have been obtained in violation of moral principles, they must not be kept. Poverty and humble station are what every person dislikes. But if they can be avoided only in violation of moral principles, they must not be avoided. If a superior person departs from humanity (ren), how can s/he fulfil that name? A 
superior person never abandons ren, even for the lapse of a single meal. In moments of haste, one acts according to it. In times of difficulty or confusion, one acts according to it'..."

In Socratic terms, one finds a striking similarity: the moral person does not "put money or anything else before virtue" (Apology 42A). Both Socrates and Confucius base their approaches upon authentic inspirational motivation. Each proposes a transcendent vision of fulfilment, justice, and peace based upon the right ordering of relationships. Each is transcendent and grasps the "beyond in our midst", a better future. Each transforms by invitation, not by coercion. Each manifests consistency between word and deed. The inspiration is simple: virtue is its own reward. The basic scenario of the moral sage in each tradition emphasises virtue and moral character. In the days leading up to his condemnation, Socrates was taken up with a single question: how to be excellent at being human? He sharply criticised the pseudo-transformational sophists - the purveyors of false wisdom - because they did not know themselves and they abandoned fidelity to the way of truth. While pretending to be wise, they were foolish. The Socratic enterprise is grounded in a relentless pursuit of the truth, in the development of wisdom and the cultivation of virtue. Indeed, Socrates himself transformed others precisely because of his fearless commitment to virtue.

For Confucius, the moral sage (shengren) is the key person in bringing about personal righteousness and social justice. A superior person (jyundz) is a moral person, who walks the moral way and attempts to practice virtue through self-cultivation. Both the sage and the superior person live under the restraint of virtue and aim to transform society accordingly. A superior person is perforce a moral leader (Analects 17:3). The common, inferior or small person (xiaoren) either does not know or does not follow the way and is not a positive moral force.

In today's world, Socrates and Confucius seem almost naive, offering a vision based on the premise that through personal cultivation, guided by moral leaders, people will develop strong moral character and embrace virtue above all other things and, in so doing, will transform themselves and society. But from this simple framework of truthwisdom-virtue a vision of the transforming power of the moral sage has flowed down through the ages. The heart of the moral enterprise is the development of good character, which is defined by commitment to virtue in all circumstances. This framework was integrated into JudaicChristian traditions through personages such as Augustine, Aquinas, and Maimonides. In Judaic-Christian traditions, the moral sage (saint, holy 
person) exercises a transforming influence upon all those whom s/he contacts. The moral sage is a leader.

While the tradition of virtue ethics has been less prominent in philosophical traditions of modern Western rationalism, it remained very much alive in religious circles (MacIntire 1981) and recently has found increasing applications in business ethics (Koehn 1995; Maitland 1997). With the renewed emphasis upon leadership in both strategic management and business ethics, the virtues and moral character of leaders have taken centre stage.

\subsection{Transformational and charismatic leadership and cultural relativity}

Broadly defined, "benevolence" is in many ways a universal value as reflected in discussions of altruism (Kanungo \& Mendonca 1996:chapter 6), as well as in the root metaphors emanating from Confucian and Socratic traditions. Yet, for example, while friendship and reciprocity may be universally valued in terms of moral excellence, they may well play out differently across cultures.

Hofstede $(1980,1997)$ presents a simple framework for analysing culture in terms of possibly universal values and practices (which he defines widely as including rituals, heroes, and symbols). For instance, friendship, love, ownership, work, fairness in exchange, are universal values found in diverse cultures throughout the world. At the same time the social customs and practices through which they are realised vary considerably (Steidlmeier 1995). It was this combination of anthropological and socio-cultural diversity, together with the notion of evolution, that struck at the heart of natural law ethics and the notion that universal and eternal moral values undergird all cultures.

For transformational and charismatic leadership to be "authentic", it must incorporate a central core of moral values. Yet the "practices" (in Hofstede's terms) of such values are highly culturally relative. Further, even when a set of core values, such as friendship or honesty, may be found in all cultures, their ordering and relative importance may also vary by culture. Add in global cultures and the possible numbers of authentic moral configurations are kaleidoscopic, even when one only deals with broad brush strokes contrasting "Western" with "Eastern" moral philosophies, or Islam with Buddhism or Christianity. Nonetheless, it is striking that out of global diversity, Christian Martin Luther King, Jr. as well as the Archbishop Tutu found inspiration in Hindu Mahatma Gandhi's philosophy of non-violence, and that human rights could become the subject of a universal United Nations declaration. 


\section{SELF-SACRIFICE IN LEADERSHIP}

Self-sacrifice in this context may be described as the total/partial abandonment, and/or permanent/temporary postponement of personal interests, privileges, or welfare in the (1) division of labour, (2) distribution of rewards, and/or (3) exercise of power.

Throughout history, there were leaders who commanded extraordinary trust and respect of their followers. Many of these leaders overcame crises by engaging in personal sacrifices. For example, Mahatma Gandhi of India was a self-sacrificial leader. He lived a life of forbearance and poverty (Gandhi 1993). He once addressed the Indian people in protest against the British rule:

"If a time comes when you have to starve, have confidence that we [the leaders] shall eat only after feeding you" (Erikson 1970: 342).

There are numerous anecdotes of this nature about Gandhi's selfhumbling and self-sacrificial life. In the Bible, there is an example of King David's leadership. When he was extremely thirsty in a battle field, some of his men broke through the Philistine lines, risking their lives, drew water from a well near the gate of Bethlehem, and offered it to David. He refused to drink the water, saying that it was blood of his men (2 Sam 23, NIV).

These stories share the common thread of leadership that involves denying self-interests or personal comfort and safety, limiting personal privileges, or sharing pains and hardships with the followers. This set of leader behaviours may be described as "self-sacrificial leadership". Selfsacrificial leadership has been alluded to in the literature over a long period of time. During the last fifteen years, it has received indirect but non-trivial attention in the transformational and charismatic leadership literature. Burns (1978) and Bass (1985) suggested that transformational leadership could involve self-sacrificial behaviours for transcendental shifts in the needs of followers. A number of charismatic leadership theories (see House 1977; Conger \& Kanungo 1987; Conger 1989; Shamir 1993; Yukl 1994) have suggested that charismatic leaders might exhibit self-sacrificial behaviours to build trust, to earn the followers' acceptance as a role model, to demonstrate loyalty and dedication to an organisation or a cause.

The phenomenon of self-sacrificial behaviours of leaders was also described in pre-1980 writings, the Asian management literature, and the popular press. In pre-1980 writings, various concepts similar to selfsacrificial leadership were introduced, such as selfless leadership (Tead 1935), self-humbling (Klapp 1968), servant leadership (Greenleaf 1977; Graham 1992 builds on and expands this idea to a more systematic 
perspective) heroic self-sacrifice, et cetera. Generally, these writings included but did not theorise about the phenomenon, and might not have been influential because they deviated from the more popular leadership paradigms of their time. In the Asian management literature, Yoon (1982) argued that leadership involves showing the example of selfsacrifice so that the leader might later ask people for sacrifices that are needed to achieve the organisational goal.

According to transformational and charismatic leadership theories, transformational and charismatic leaders might use self-sacrifice as a demonstration of loyalty and dedication to an organisation or a cause, as a symbolic expression of courage and conviction in a mission (Shamir 1992), as a means to build trust (Conger 1989), as a strategy to earn credibility and acceptance as a role model (Shamir 1993), etcetera. The literature suggests that a leader's unconventional behaviour will be positively associated with the followers' perception of the leader's charisma (Bass 1985; Kanungo 1988; Conger 1989; Yukl 1994). Such a prediction seems to be in agreement with the numerous anecdotes of such leaders as Jesus Christ, Mahatma Gandhi, Abraham Lincoln, Martin Luther King, Jr., Nelson Mandela and the Archbishop Tutu, who exhibited self-sacrificial behaviours.

In 1995 President Nelson Mandela appointed Archbishop Tutu to chair South Africa's Truth and Reconciliation Commission, the body set up to probe gross human rights violations between 1960 and the President's inauguration in 1994. Archbishop Tutu has remarked on numerous occasions that he has been appalled at the evil the Commission has uncovered, but that it has been a "privilege" to be part of a process of trying to heal a traumatised and wounded people. Quite often the compassion of leaders takes its toll on individuals - physically as well as mentally - as it also has on Tutu who suffered prostate cancer (quoted in BBC Online Network, Friday, July 31: 1998):

"Listening to all the pain and anguish, you take it into yourself in many ways.... maybe one day you will sit down when you think of all those things and you will cry".

\section{LEADING WITH COMPASSION IN TIMES OF TRAUMA}

When people think of compassion, the first thing that comes to mind is empathy. But while empathy can be comforting, it does not engender a broader response, and therefore has limited capacity for healing. Instead, compassionate leadership involves taking some form of public action, however small, that is intended to ease people's pain - and that inspires others to act as well. 
For a historical perspective on compassionate leadership, an example might be Britain's Queen Mother, who demonstrated great courage by refusing to leave London as bombs ravaged the city around her during World War II. She and King George visited sites that had been destroyed during the Blitz of 1940, showing her dedication, concern, and commitment to the Allied cause, and inspiring lifelong admiration and loyalty for her constant presence (Dutton et al 2002).

Such leaders facilitate a compassionate response on two levels. The first level is a context for meaning - the leader creates an environment in which people can freely express and discuss the way they feel, which in turn helps them to make sense of their pain, seek or provide comfort, and imagine a more hopeful future. The second level is a context for action - the leader creates an environment in which those who experience or witness pain can find ways to alleviate their own and others' suffering. Those leaders who excel at leading compassionately and effectively in times of crisis adhere to a set of shared practices that help people make sense of terrible events and allow people to move on. This meaning-making process can also be supported by communicating and reinforcing values - reminding people about the larger purpose of their life and work even as they struggle to make sense of major life issues.

\section{DESMOND TUTU AS SERVANT LEADER AND COMPAS- SIONATE ZEALOT}

In a world drowning in pontificators and pretenders and self-promoters of every stripe, all jockeying to outshoot the other - Desmond Tutu is that rare commodity who lives up to his advanced billing. Amongst all the world leaders - famous and infamous - he has proven to be a leader with humility and compassion.

\subsection{A servant leader}

George Bernard Shaw once observed that the reasonable man adapts himself to the world, while the unreasonable man persists in trying to adapt the world to him. Tutu is such an "unreasonable man". What South Africa needed before 1994, throughout the Truth and Reconciliation Commission, and what the world needs right now, is exactly "unreasonable men" as leaders. There are those who maintain that Tutu's forgiveness had verged on the autocratic during the Truth and Reconciliation Commission (Hattenstone 2001). At times he seemed to have demanded forgiveness from Commission witnesses simply unwilling, or unready, to forgive. The Archbishop has never been afraid to stimulate controversy, nor constructive conflict and dissent. He is a healing leader - prepared to 
facilitate people and society to grow emotionally, intellectually and spiritually.

An emerging approach to leadership is servant leadership. It leads from the concept of healing leadership to emphasise the importance of increased service to others - a holistic approach to work, the promotion of a sense of community, and a deeper comprehension of the spirit in the workplace and in society (Greenleaf 1998). Archbishop Desmond Tutu demonstrates such leadership. His work and his beliefs became a way of life and he has never changed his consistency in thinking. As a servant leader, he became familiar with the "pain" as well as the "gain" of transformation and change.

\subsection{A compassionate zealot}

When great leaders are asked to talk about the frenetic pace of their lives, they are typically reacting to the multiple demands placed on them in three arenas at once. They are simultaneously called upon to create value; to align people to value and to deliver value (Branstad \& Lucier 2001:42). Even the most admired leaders find it difficult to pursue all three of these imperatives at the same time - but Desmond Tutu succeeded in doing exactly this.

In leadership and management a particular individual emerged prominently through the ages to lead this charge. Branstad \& Lucier (2001:44) call these individuals zealots. Archbishop Desmond Tutu can be viewed as a compassionate zealot. Zealots are practical visionaries and are zealous. The word zealous that derives from the Greek for fervour and rivalry has two connotations. The original Biblical-era zealots were members of outlaw bands, often at odds with local rulers. This passion often translated into martyrdom, as it did at Masada. In the corporate leadership environment, though, the word carries a different meaning: a person with enough passion for an endeavour to put himself or herself, but not the organisation, the people or the cause, at risk (Branstad \& Lucier 2001:44). In this context, then, a zealot is a person who is willing to make him or herself uncomfortable in the pursuit of a larger purpose, and to cause others to be uncomfortable as well, all for the ideal of transformation, change and growth. Archbishop Tutu played such a role during the apartheid years, during the Truth and Reconciliation Commission, in the fight against HIV/Aids, as promoter of leadership education and training, and as the moral voice and conscience of the world in its efforts to seek peace.

Even in times where there is an abundance of "revolutionaries" and "change agents", zealots are noteworthy individuals. During the apartheid regime, there were numerous revolutionaries and voices 
against the system - some with violence as an end to their means. But none of the voices were as strong as the voice of Desmond Tutu.

As a world leader, Archbishop Desmond Tutu has been a living illustration of visionary leadership by always creating value. Some of his visionary ideas - directly and indirectly - became reality. Amongst the numerous awards he has received, the following are particularly aligned with leadership in action: The Distinguished Peace Leadership Award (by the Nuclear Age Peace Foundation in 1990); the Planetary Consciousness World Leadership Prize (by the Club of Budapest in 1998); the President's Award (by the International Public Relations Association in 1992); the Reach and Teach USA Renaissance Individual Leadership Award in 1999, and the Toastmasters International Communication and Leadership Award in 1997.

In May 2002 the Archbishop was in Seattle to drum up support for a new foundation that aims to promote peace, reconciliation and restorative justice, by training leaders according to the lessons learnt from the battlefield - South Africa. This foundation hopes to offer leadership training throughout the United States of America and abroad, as well as to generate income for the Desmond Tutu Peace Centre, launched in Cape Town in 2000 (Shapiro 2002). At this centre, people from all over the world can reflect on such issues as diversity, education and the need for scarred communities to live responsibly in peace.

The Archbishop has also launched an initiative that seeks to help develop leadership skills at all levels in African countries through the Desmond Tutu Leadership Academy, launched as part of the Peace Centre in Cape Town in August 2001. This academy aims to find and educate leaders in fields such as community development, management, academia and politics. The ideal of this academy is to eradicate the leadership crisis, which is one of the greatest obstacles to development in South Africa.

\section{CONCLUSION}

The craving for a glimpse of the future has a long tradition in human history. People are accustomed to ask their gods, priests, or wise men about the nature of the future. They used chicken bones, crystal balls, and palmistry of stars as a means of divination. Since the beginning of the field of strategic management and leadership in the late 1960s and early 1970s, new theories, methods and concepts have been developed that aim at explaining differences in corporate performance and help managers and leaders to think about the future of their companies.

There is a notion that the future is ever changing, complex and predictable. If this notion is true, leadership should develop to anticipate, respond and be proactive as well as interactive within such an environ- 
ment: "sensing" the future rather than "seeing" it (West 1995:11). Leaders will then have to understand and cope with change, so that change in itself does not become destructive. During the apartheid years and the Truth and Reconciliation Commission, this was exactly how Archbishop Tutu operated. There was always a glimmer of hope and forgiveness. He understood the patterns of events, interpreted them and then made suggestions about how they should be dealt with. Hence, intelligent and responsible "dealing" must be about sensing how such suggestions will affect the future, having care for its sustenance.

During the apartheid years, Archbishop Tutu vigorously attempted to ensure that South Africa operated within an informed ethical framework that would form part of a wider social ethic. He realised during the Truth and Reconciliation Commission's operations that as a society South Africa could move into a discontinuous and chaotic reality that could either mean utopia or dystopia. With a tremendous exercise of power that sometimes drained him physically and emotionally, the Archbishop moved forward. South Africa, with all its current problems, had a peaceful transition to democracy and due to the assistance of Desmond Tutu, it made peace with its tainted history to become an example to the rest of the world.

$\mathrm{He}$ is often asked to assist in achieving peace and reconciliation where there is strife in the world. The timing could not have been better. Conflicts are now experienced in many places across the globe. South Africa is a beacon of hope for ending a strife that seemed intractable for many years. Perhaps the Archbishop Desmond Tutu is now in a better position than ever to offer solutions for both the War on Terrorism and the frenzied violence in the Middle East. In these troubled times - when the world has to deal with a resurgence of cultural and religious conflict - a servant leader such as Tutu might play a pivotal role.

\section{Consulted literature}

Bass, B M 1985. Leadership beyond expectations. New York: Free Press.

Bass, B M \& Steidlmeier, P 1999. Ethics, character, and authentic transformational leadership, Leadership Quarterly, Summer 1999, 10 (2).

BBC Online Network, July 1998. World: Africa. Profile of Archbishop Tutu.

Branstad, P \& Lucier, C 2001. The case for practical visionaries. Business \& Strategy, 22: 42-53.

Burns, J.M 1978. Leadership. New York: Harper \& Row.

Confucius 1993. The Analects. Translated by R Dawson. Oxford: Oxford University Press.

Conger, J A 1989. The charismatic leader: behind the mystique of exceptional leadership. San Francisco: Jossey-Bass.

Conger, J A \& Kanungo, R 1987. Toward a behavioral theory of charismatic leadership in organizational settings. Academy of Management Review, 12:637-647. 
-, 1988. Charismatic leadership: the elusive factor in organizational effectiveness. San Francisco: Jossey-Bass.

-, 1998. Charismatic leadership in organizations. Thou-sand Oaks, CA: Sage Publications.

De Bary, W T 1991. The trouble with Confucianism. Cambridge, MA: Harvard University Press.

Dutton, J E, Frost, P C, Monica, Lilius, J M, Kanov, J M 2002. Leading in times of trauma, Harvard Business Review, January 2002, 80(1).

Erikson, E 1970. Gandhi's truth: on the origins of militant non-violence. New York: Norton.

Fairholm, G W 1998. Perspectives on leadership: from the science of management to its spiritual heart. Westport, CT: Quorum Books.

Gandhi, M 1993. An autobiography: the story of my experiments with truth. Translated by Mahadev Desai. Boston, Mass: Beacon Press.

Graham, J W 1991. Servant leadership in organizations: inspirational and moral. The Leadership Quarterly 2:105-119.

Greenleaf, R K 1977. Servant leadership. New York: Paulist Press.

-, 1998. The power of servant leadership. San Francisco: Berrett-Koehler.

Hambrick, D C, Nadler, D A, \& Tushman, M L (eds) 1998. Navigating change: how CEOs, top teams, and boards steer transformation. Boston, Massachusetts: Harvard Business School Press.

Hattenstone, S 2001. Freedom's father. The Guardian (Interview).

Hofstede, G 1980. Culture's consequences: international differences in work-elated values. Beverly Hills, CA: Sage Publications.

-, 1997. Cultures and organizations: software of the mind. New York, NY: McGraw-Hill.

House, R J 1977. A 1976 theory of charismatic leadership, in Hunt, J G \& Larson, L L (eds), Leadership: the cutting edge. Carbondale: Southern Illinois University Press, 189-207.

House, R J \& Shamir, B 1993. Toward the integration of transformational, charismatic, and visionary theories, in Chemers, M M \& Ayman, R (eds), Leadership theory and research: perspectives and directions. Orlando, FL: Academic Press, 81-107.

Howell, J M, \& Avolio, B J 1992. The ethics of charismatic leadership: submission or liberation? Academy of Management Executive, 6 (2):43-54.

Hunt, J G 1991. Leadership: a new synthesis. Newbury Park, CA: Sage.

Kanungo, R N, \& Mendonca, M 1996. Ethical dimensions in leadership. Beverly Hills, CA: Sage Publications.

-, 1998. Charismatic leadership: the elusive factor in organizational effectiveness. San Francisco: Jossey-Bass Publishers.

Koehn, D 1995. A role for virtue ethics in the analysis of business. Business Ethics Quarterly, 5:533-540.

Klapp, O E 1968. Symbolic leaders: public dramas and public men. Chicago: Minerva Press.

MacIntyre, A 1981. After virtue: a study in moral theology. Notre Dame, in: University of Notre Dame Press.

Maitland, I 1997. Virtuous markets: the market as a school of virtues. Business Ethics Quarterly 7:17-31.

Morgan, G 1986. Images of organization. Newbury Park, CA: Sage. 
Mumford, M D, Zaccaro, S J, Harding, F D, Jacobs, T O, Fleishman, E A 2000. Leadership skills for a changing world: solving complex social problems. Leadership Quarterly, 11(1).

Mumford, M D \& Van Doom, J R 2001. The leadership of pragmatism: reconsidering Franklin in the age of charisma. Leadership Quarterly, 12(3), Fall 2001.

Plato. 1937. The Apology; Phaedo, and, Crito of Plato. Translated by B Jowett. New York: Collier.

Rogers, C R, \& Farson, R E 1955. Active listening. Chicago, IL: Industrial Relations Center, University of Chicago.

Sankowsky, D 1995. The charismatic leader as narcissist: understanding the abuse of power. Organizational Dynamics, 23, 57-71.

Shamir, B, House, R J, \& Arthur, M B 1993. The motivational effects of charismatic leadership: a self-concept based theory. Organization Science, 4:1-17.

-, 1995. Social distance and charisma: theoretical notes and an exploratory study. Leadership Quarterly, 6:19-47.

-, 1999. Leadership in boundaryless organizations: disposable or indispensable? European Journal of Work and Organizational Psychology, 8:49-72.

Shamir, B, \& Ben-Arie, E (1999). Leadership in an open army? Civilian connections, interorganizational frameworks, and changes in military leadership, in: Hunt, J G, Dodge, G E \& Wong, L (eds), Out-of-the-box leadership: transforming the twenty-first century army and other top performing organizations Stamford, CT: JAI Press, 15-42.

Shapiro, N 2002. Peace now, but how? Desmond Tutu passed up a chance to offer solutions for the current world of violence. Seattle Weekly (Interview).

Schwartz, B I 1985. The worm of thought in ancient China. Cambridge, MA: Belknap Press of Harvard University Press.

Steidlmeier, $\mathrm{P}$ 1995. Strategic management of the China venture. Westport, CT: Quorum Books.

Taylor, R L, \& Arbuckle, G 1995. Confucianism. The Journal of Asian Studies, 54:347-353.

Tead, O 1935. The art of leadership. New York: Whittlesey House.

$\mathrm{Tu}, \mathrm{W}$ 1985. Confucian thought: selfhood as creative transformation. Albany, NY: State University of New York Press.

Weber, M 1924/47. The theory of social and economic organizations. New York: Free Press.

Wren, J T 1998. James Madison and the ethics of transformational leadership, in: Ciulla, J (ed) Ethics, the heart of leadership. Westport, CT: Praeger, 145-168.

Yoon, S C 1982. A framework for managerial thoughts (Published in Korean. Original Title: Kyongyonghak jok Sago eui Teul). Seoul, Korea: Kyung Moon Sa.

Yukl G A 1994. Leadership in organizations (3rd ed). Englewood Cliffs, NJ: Prentice Hall. 